\title{
O habitus dos policiais militares do Distrito Federal
}

Rodrigo Figueiredo Suassuna

Curso: Mestrado em Sociologia

Data da defesa: 4 de julho de 2008

Orientadora: Prof ${ }^{\mathrm{a}}$. Dr ${ }^{\mathrm{a}}$ Maria Stela Grossi Porto

\section{Resumo}

A presente dissertação tem como tema as práticas policiais, mais precisamente, o habitus dos policiais militares do Distrito 
Federal (DF). No trabalho, habitus é entendido como a composição social dos indivíduos biológicos, ou seja, o resultado da incorporação, pelo indivíduo policial militar, das necessidades objetivas de sua vida social. Busca-se a compreensão das distinções e classificações que compõem o habitus dos policiais militares, bem como as funções que essas distinções desempenham como sentido orientador da ação e como padronização da auto-restrição individual. Além disso, trata-se das necessidades práticas que estruturam cada uma dessas distinções.

Dentre as distinções do habitus policial militar, enfatizaram-se as considerações de risco, este entendido como a representação das perdas e dos danos que decorrem de determinada ação individual. Inicialmente, a dissertação trata da questão do risco de ocorrência de crimes, conforme consideração pelos policiais militares do DF. Outro conteúdo com que o conceito de risco aparece no habitus desses agentes refere-se ao risco de danos físicos e perda da vida. Com relação ao risco de ocorrência criminal, o estudo concluiu que a prisão de criminosos é uma função central desempenhada pelos policiais militares, segundo as classificações de seu habitus. Para o cumprimento de tal função, o habitus dos agentes da lei mostra disposição para a individualização e a objetivação do elemento suspeito. A ênfase sobre a prisão de criminosos e, conseqüentemente, o padrão cultural de suspeição policial são distinções formadas a partir de necessidades práticas inter-relacionadas e que se ligam ao uso da autoridade coercitiva pelos policiais militares. Além disso, acrescenta-se como conclusão a observação de que a definição de crime no habitus policial militar é mais abrangente do que a que se estabelece no interior do sistema de justiça penal. A abrangência das definições de crime e de suspeito tem como origem, em parte, o desajuste dos policiais militares à diversidade moral própria da vida urbana. Tem-se ainda que as categorias normativas do habitus policial militar que se relacionam à proteção física do policial e à responsabilização das ações policiais favorecem a efetividade do 
autocontrole individual. Finalmente, conclui-se que as possibilidades de ocorrências fisicamente danosas no trabalho policial militar são incorporadas pelos policiais como consideração de risco à própria vida e à integridade física.

Palavras-chave: polícia; cultura policial; segurança pública. 